\title{
The modern science of acmeology: integration of psychology and pedagogy in education
}

\author{
L. Ye. Pautova ${ }^{1, *}$, and Ye.N. Zharinova ${ }^{2}$ \\ ${ }^{1}$ Federal state budgetary scientific institution All-Russian scientific and research institute of irrigation \\ and farming water supply systems "Raduga", Kolomna, Russia \\ ${ }^{2}$ FGBOU VO "Saint Petersburg State University of Veterinary Medicine", Saint Petersburg, Russia
}

\begin{abstract}
The purpose of this study is to analyse and define the structural and substantive characteristics of acmeological categories (terms) with regard to fundamental education. The authors carried out theoretic and historical, methodological, systemic and logical analysis of acmeological, psychological and pedagogical studies on efficiency of education system and conceptual framework of creative professional and educational activities. Results of studying and substantiating of acmeological categories (terms) of creative activities within the system of fundamental education are presented in detail. Their structural and substantive features are identified and classified. The study presents categorization of acmeological concepts that integrate psychology and pedagogy. Results of this study can be used 1) as a scientific and methodological basis of fundamental education, particularly for vocational creative activities and for teaching the acme of productivity and professionalism; 2) for classification of acmeological categories and their incorporation into the conceptual framework of the Russian fundamental education.
\end{abstract}

\section{Introduction}

The modern science of acmeology, which integrates psychology and pedagogy in the context of education, includes a new system of concepts that require classification. While psychology is defined as the science that studies the laws of reflection of objective and subjective reality in mental processes, the main distinctive trait of acmeology is studying the laws of human creative activities. Creative activities include all mental processes and properties of reflection, but are not limited to them. In creative activities it is important to form an image of the desired result, to form acme-targeted strategies of translation of the desired result into a real product, and to evaluate quality of this translation. Pedagogy is mainly a normative science. What should a student, a teacher, or a director do? Acmeology views the modern education as a process of solving numerous pedagogic, educational, motivating and evaluative challenges.

\footnotetext{
* Corresponding author: cosidanie35@yandex.ru
} 


\section{Materials and methods}

As the methodological basis the authors present an overview of various areas of research on acme-psychological and pedagogical activities of students of different specializations. Research methods used in the study include comparative, systemic and logical, methodological, theoretic and historical types of concept analysis.

\section{Results and discussion}

As a modern integrative science, acmeology needs a categorization of its basic concepts, which are to be reviewed in this study. A "category" (from Greek katēgoria - feature, statement). Philosophy defines general fundamental concepts, which reflect the most essential and natural connections and relations between reality and cognition.

Acmeological categories are characterized by the presence of an occurrence in objective reality, in the behaviour of a person, and in the vertical and horizontal interactions. They are connected by a commonality of significant features, for example, levels and peaks of productivity, abilities, readiness for professional activity, or productive competence. Training of productive competence is considered successful when it introduces the categories of mental products and "potentials" (inclinations, aptitude) even to elementary school students and teenagers. They should know that getting high grades means self-development not only for today, but for the rest of their lives. This is something that serves the others as well, but primarily it serves the subject of self-organization, selfeducation and self-control, for today and for life.

The main function of categorization is to specify and to generalize the four definite features of the phenomenon in question into a fundamental concept. The category of productivity peaks of regions, municipalities, educational institutions and academic disciplines can be identified by the ranking data of common, management and research education specialists - in accordance with a uniform criterion for the quality of education. Top teachers of academic disciplines, such as physics, chemistry and mathematics, can be classified according to:

1. The student performance - the number of high-, average-, and low-performing students;

2. The number of graduates entering professional schools - everybody, absolute majority, half, or few;

3. The number of participants and winners of academic competitions of various levels - municipal, regional, and federal;

4. The number of student publications;

5. The number of student inventions of various levels of recognition.

The top managers of educational institutions can be classified according to the objective indicators of the student results, and inclusion in the systems, such as educational and production on the one hand, and penitentiary, on the other hand.

In the context of the acmeological theory of fundamental education by N.V. Kuzmina the following main categories and concepts of creative activities in the system of fundamental education are defined [5, pp. 37-77]:

- The category of the mental product created by means of education;

- The category of natural potentials, inclinations and aptitude of subjects of creative and self-creative activities;

The category of self-actualization in psychology and self-fulfilment of natural potentials in the form of created products;

The category of the top self-fulfilment of the natural potentials of geniuses in the form of created products; 
- The category of outstanding self-fulfilment of talented people in the form of created products;

- The category of successful self-fulfilment of skilled people in the form of created products;

- The category of mastery in creation of mental products by means of academic disciplines;

- The category of coordination of subjects efforts creating mental products.

The characteristics of the main acmeological categories are shown in the Table 1.

Table 1. The characteristics of the main acmeological categories of fundamental education.

\begin{tabular}{|c|c|c|}
\hline № & Acmeological category & Distinctive features \\
\hline 1 & $\begin{array}{l}\text { The category of the mental product created } \\
\text { by means of education }\end{array}$ & $\begin{array}{l}\text { Physical, psychic, acmeological newly } \\
\text { formed structures in the properties of } \\
\text { participants of the educational process; } \\
\text { complex activities within the process of } \\
\text { acme-energy-informational long-term } \\
\text { interaction between teacher and students, } \\
\text { and between students and objects of } \\
\text { communication, perception and work; } \\
\text { acme-targeted strategies for diagnosing } \\
\text { factors contributing to or preventing the } \\
\text { creation of mental products }\end{array}$ \\
\hline 2 & $\begin{array}{l}\text { The category of natural potentials, } \\
\text { inclinations and aptitude of subjects of } \\
\text { creative and self-creative activities }\end{array}$ & $\begin{array}{l}\text { "Natural characteristics of a person", } \\
\text { "inclinations", "aptitude", "natural gifts"; } \\
\text { hidden capacities manifested in abilities, } \\
\text { talents, genius, personality traits, styles of } \\
\text { activity, identity, creations and products } \\
\text { being made; } \\
\text { lifelong self-development of a human as an } \\
\text { individual, a unique person, a doer, starting } \\
\text { from birth }\end{array}$ \\
\hline 3 & $\begin{array}{l}\text { The category of self-actualization in } \\
\text { psychology and self-fulfilment of natural } \\
\text { potentials in the form of created products }\end{array}$ & $\begin{array}{l}\text { Acknowledgement of the leading role of } \\
\text { creativity in a person; } \\
\text { overcoming the cultural stereotype of } \\
\text { masculinity; } \\
\text { manifests in actions related to self- } \\
\text { identification search and the need to find } \\
\text { and keep self-identity; }\end{array}$ \\
\hline 4 & $\begin{array}{l}\text { The category of the top self-fulfilment of the } \\
\text { natural potentials of geniuses in the form of } \\
\text { created products }\end{array}$ & $\begin{array}{l}\text { The peaks of human spirit, existing for } \\
\text { centuries and influencing the development } \\
\text { of humanity even after hundreds since a } \\
\text { person's death; } \\
\text { the levels of top representatives; } \\
\text { excitation of brain activity, thinking and } \\
\text { mental activity by various means }\end{array}$ \\
\hline 5 & $\begin{array}{l}\text { The category of outstanding self-fulfilment } \\
\text { of talented people in the form of created } \\
\text { products }\end{array}$ & $\begin{array}{l}\text { Is connected to the products of creativity } \\
\text { made by talented people; } \\
\text { subjective and objective circumstances that } \\
\text { allowed them to realize the general and } \\
\text { specific patterns of creativity and } \\
\text { development of artistic talent during the } \\
\text { search period; } \\
\text { defines professional techniques and } \\
\text { mastery }\end{array}$ \\
\hline 6 & $\begin{array}{l}\text { The category of successful self-fulfilment of } \\
\text { skilled people in the form of created } \\
\text { products }\end{array}$ & $\begin{array}{c}\text { Levels of self-fulfilment; } \\
\text { successful solutions of upcoming tasks } \\
\text { facing a new educational or professional } \\
\text { environment; } \\
\text { is fulfilled in the acme-energy- } \\
\text { informational interaction with students }\end{array}$ \\
\hline
\end{tabular}


Table 1. Continued.

\begin{tabular}{|c|c|c|}
\hline 7 & $\begin{array}{c}\text { The category of mastery in creation of } \\
\text { mental products by means of academic } \\
\text { disciplines }\end{array}$ & $\begin{array}{c}\text { Professionalism in teaching activities; } \\
\text { professional maturity, readiness for creative } \\
\text { work, indicators of the expected results; } \\
\text { high level of productive activities and } \\
\text { freedom of communication }\end{array}$ \\
\hline 8 & $\begin{array}{c}\text { An invariant image of the mental product } \\
\text { created in the properties of participants of } \\
\text { the educational process by means of } \\
\text { academic disciplines; } \\
\text { encouragement of students to fulfill their } \\
\text { The category of coordination of subjects } \\
\text { efforts creating mental products } \\
\text { of peaks of productive solutions to the } \\
\text { eductional problems; } \\
\text { development of productive competence and } \\
\text { skills providing a high level of labour } \\
\text { productivity and creation of competitive } \\
\text { products for everyone or the majority of } \\
\text { graduates }\end{array}$ \\
\hline
\end{tabular}

\section{Conclusion}

Summarizing the results of the theoretical analysis by features of acmeological categories, it is advisable to identify their acmestrategic direction within the system of fundamental education by the following characteristics:

- Program of activities of a specialist;

- System of connections according to the goals of an individual;

- Set of values;

- New possibilities for self-fulfilment of creative potential;

- Achievement of the desired product.

The originality and scientifically-practical novelty of the discussed acmeological categories are based on:

- The possibility of practical implementation of the acmeological theory of fundamental education by N.V. Kuzmina within the system of scientific and methodological support of the professional activity of a teacher of a professional school.

- The definition of the particular characteristics of the acmeological terms with regard to the productive professional and educational interaction.

- The transfer of historical, theoretical, methodological and acmeological experience, development of the scientific and practical acmeological support, as well as educational and methodological materials of productivity of professional and educational activity on its basis.

Acceptance and inclusion of the analyzed acmeological categories into the system of scientific concepts of fundamental education will therefore allow us to understand and systematize the distinctive features of acmeology as a science while solving theoretical, scientific and practical issues in the quality of education and professional activity of education specialists.

\section{References}

1. B. G. Anan'yev, Essays on Psychology (1945)

2. A. A. Derkach, Acmeological foundations of professional development (2004)

3. Ye. N. Zharinova, Psychological and Acmeological Technologies in Education, Monograph (2015) 
4. Ye. S. Kuz'min, Osnovy sotsial'noi psikhologii (1967)

5. N.V. Kuz'mina, Acmeological theory of fundamental education (2012)

6. N.V. Kuz'mina, L.Ye. Varfolomeyeva, Ye. N. Zharinova, Acmeological foundations of the development of communicative culture and creative readiness of a bachelor, master, specialist (2015)

7. M.A. Manoilova, Acmeology of Ethnic Tolerance of Objects of Fundamental Education (2010)

8. L.Ye. Pautova, Methodological foundations of the "act of strategy" in the teacher's professional activity, Acmeology: theory, practice and development prospects (2018)

9. S.D. Pozharskiy, Psychology of development, 1(3), 7 (2012)

10. S.A. Kravchenko, Polis (Russian Federation), 4, 185 (2018)

11. N.N. Nechaev, Cultural-Historical Psychology, 14(3), 57 (2018)

12. N.N. Pachina, V.P. Kuzovlev, N.V. Kuzovleva, J. of Advanced Research in Law and Economics, 8(22), 28 (2016) 